STATE OF ALASKA

William A. Egan - Governor

DEPARTMENT OF NATURAL RESOURCES

Phil R. Holdsworth - Commissioner

DIVISION OF MINES AND MINERALS

James A. Williams - Director

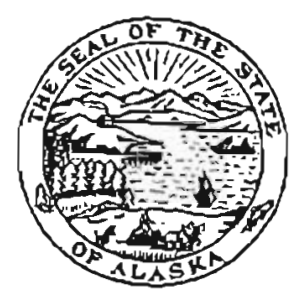

\begin{abstract}
GEOLOGIC REPORT NO. 7
Geology of the Dry Pass Area,

Southeastern, Alaska
\end{abstract}

By

Gordon Herreid and M. A. Kaufman

Juneau, Alaska

June 1964 


\title{
GEOLOGY OF THE DRY PASS AREA,
}

SOUTHEASTERN ALASKA

\author{
By \\ Gordon Herreid \& M. A. Kaufman
}

\section{INTRODUCTION}

Present interest in the Dry Pass area is the result of a new discovery of molybdenite by $\mathrm{Mr}$. Angus Lillie of Tokeen, Alaska, who has prospected in the area for a number of years. During May 1963 the authors spent 10 days field-mapping the area, and one day examining the showings at Devilfish Bay, 5 miles to the southeast. We are indebted to Mr. Lillie for guidance to the various showings. His familiarity with the mineral deposits and the geology greatly facilitated the field work.

The map area is located on Kosciusko Island, 45 miles WSW of Wrangell. It has no permanent inhabitants. The terrain has been glaciated, and as a result has many lakes, sharp relief with numerous cliffs, and little or no soil cover on most of the upland. Most of the area is heavily timbered with no underbrush, and bedrock is covered by a thin mantle of moss and forest litter. Bedrock exposure is estimated to be less than 5 per cent of the area, exposures being present mainly along streams, on cliffs, and at the roots of fallen trees.

A marble quarry has been worked north of the map area, and a high grade molybdenum-chalcopyrite vein has been explored on the south edge of the map area. The work on the vein took place during and after the first World war. It has been reported on in several U.S. Geological survey Bulletins, the most recent of which (Robinson, 1946) gives measured and indicated reserves of 10,000-20,000 tons of 1.5 per cent Mos $_{2}$. 


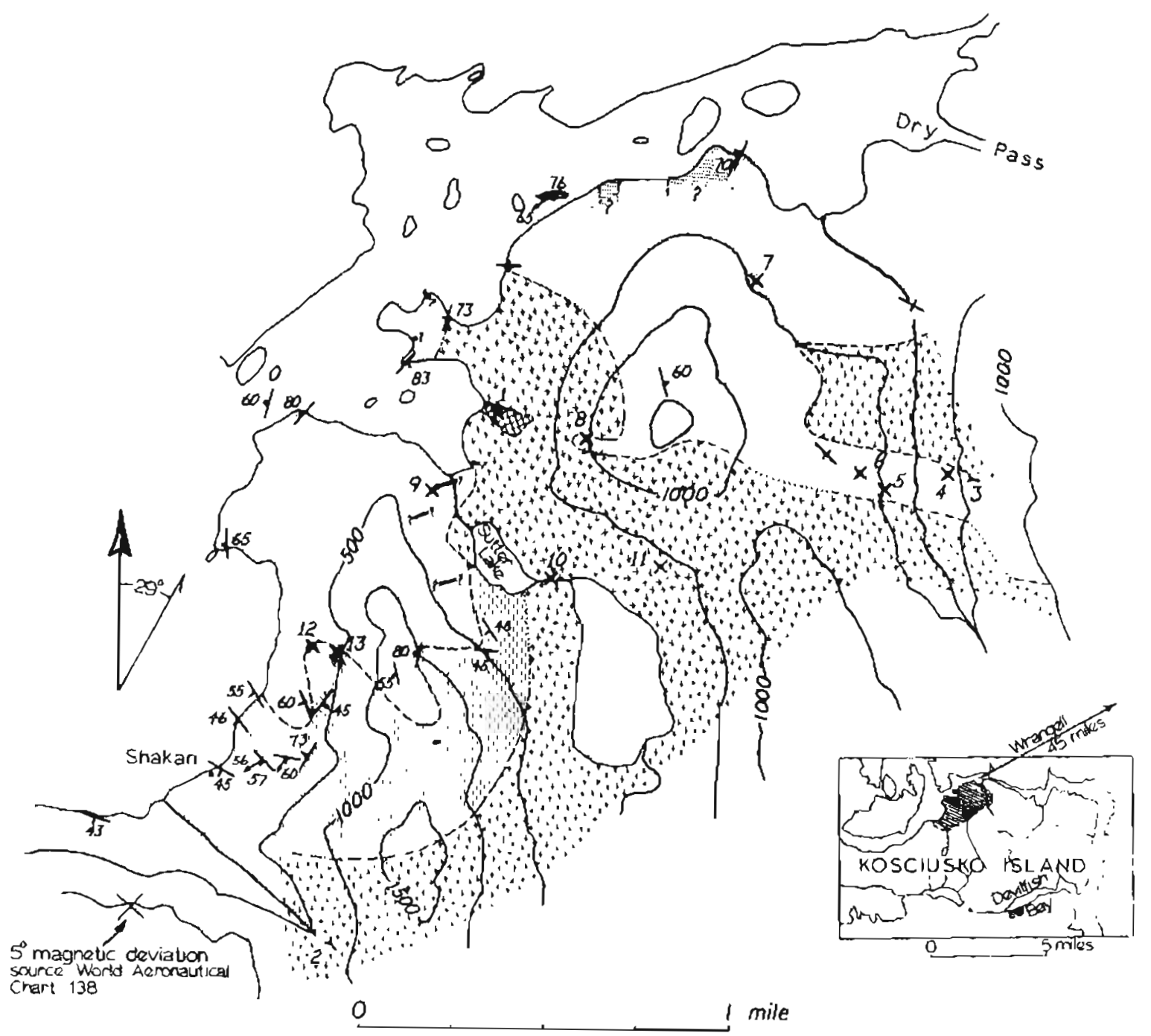

GEOLOGIC MAP OF THE DRY PASS AREA

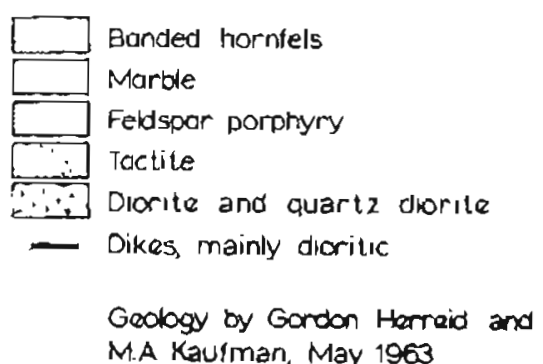

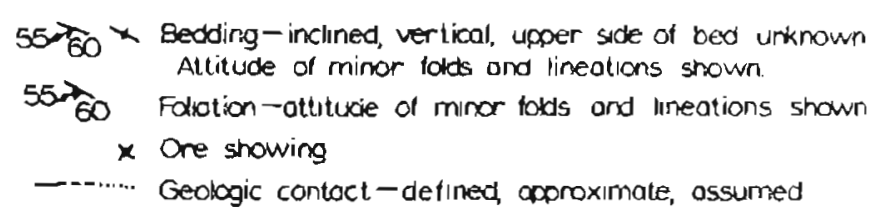

Topograpty trom U.S Forest Servee 1.31,680 map of the Petersburg (A-5) auadrangle 


\section{GEOLOGY}

Buddington and Chapin (1930 Plate 1) map a wide area around Dry Pass as underlain by limestone and graywacke of silurian age and cut by a $5 \times 15$ mile diorite-to-granite batholith. They describe the regional structure as a synclinorium with most folds trending northwestward. The map area of this report lies along the west side of the batholith. Bedrock is banded axgillite, marble, and graywacke which has been intruded by hornblende diorite. Contact metasomatized sedimentary rock (tactite) occurs locally, with or without associated molybdenite, chalcopyrite, scheelite, and magnetite.

Sedimentary Rocks:

Marble - The calcareous rock in the area has been contact metamorphosed to a light gray marble with grains up to 1 mm in diameter. This rock is rudely foliated with the surfaces parallel to the general orientation of faint gray bands about $1 \mathrm{~mm}$ wide. These gray bands interlace so as to outline lenticular rods of the light gray marble which plunge steeply southwest. The southwest plunging rods lie parallel to the foliation planes and give the rock exposures a fluted or lineated surface. The marble is in gradational contact with the banded hornfels.

Banded hornfels - The southwest part of the area is underlain by dark fine-grained conspicuously banded hornfels with brownish gray to greenish gray layers which represent original bedding. These bands are generally 1 to 2 inches thick. In places fine-grained dark gray limestone bands occur. With an increase in the percentage of limestone beds the rock grades into the massive marble described previously. Along the shore just north of shakan this change takes place over a distance of about 400 feet.

The hornfels is composed of subhedral andesine and orthoclase feldspar crystals (generally less than $0.1 \mathrm{~mm}$ long) in a finegrained quartzose groundmass with patches of calcite. Masses and scattered grains of clinopyroxene about the same size as the feldspar replace the feldspars and groundmass and make up an estimated 20 to 30 per cent of the rock. No schistosity or preferred orientation of mineral grains is present. Development of the pyroxene is due to contact metamorphism of the previously folded calcareous siltstone by the Dry Pass intrusive.

Age relationship of sedimentary rock units - The gradation of the banded graywacke-siltstone into marble indicates that these rocks are part of the same sedimentary sequence. No evidence was 
found to indicate the age of the rocks or to determine whether the banded argillite lies stratigraphically above or below the limesicone.

Igneous Rocks:

Feldspar porphyry - Along the north side of the map area porphyritic sills (?) are present in the limestone. The porphyry is composed of subhedral andesine grains up to 4 mo long in a finegrained quartzose groundmass. Randomly oriented fine-grained biotite (about 5 per cent of the rock) and actinolite (less than 1 per cent) replace the groundmass and to some extent the andesine. The development of biotite and actinolite in the rock is a contact metamorphic effect associated with the Dry Pass intrusive. Their presence dates the porphyry as pre-intrusive in age. A few fine pyrrhotite (?) grains occur in this rock.

Dry Pass batholith - The marginal parts of the Dry Pass batholith which fall in the map area vary from diorite to granodiorite in composition. Megascopically the rock varies from light colored granodiorite and quartz diorite of granitic appearance to a darker colored diorite and monzonite which in places contains up to 25 per cent rudely oriented hornblende phenocrysts. These rocks are Exesh and unaltered to clay or limonite, even where they carry a small percentage of sulfide ore minerals. An estimated 1 to 2 per cent of disseminated $\mathrm{Fe}, \mathrm{Cu}$, and $\mathrm{Mo}$, sulfides were seen in places in the intrusive. Quartz veins are present locally and may contain a small percentage of these sulfides.

Four specimens of the intrusive have been examined microscopically. These are all medium-grained granular rock with phonocrysts of subhedral hornbiende (to $2-3 \mathrm{~mm}$ ) and anhedral clinopyroxene (to $2 \mathrm{~mm}$ ) set in a matrix composed essentially of subhedral plagioclase crystals about $1 \mathrm{~mm}$ in length. Quartz and a small percentage of orthoclase occur as irregular interstitial patches between the plagioclase and mafic grains. Sphene, magnetite, and apatite are scattered throughout the rock, mainly along crystal boundaries, particularly at the edge of the mafics, but also between plagioclase grains. Magnetite and sphene also occur as inclusions in the hornblende and pyroxene phenocrysts. Pyrite is comonly associated with epidote and quartz in irregular patches replacing plagioclase mainIy along grain boundaries.

A two-stage cooling history of the intrusive is suggested by the plagioclase grains. Many are zoned and these commonly have clear rims with oscillatory zoning around older, fractured, somewhat altered cores. In scme grains these cores have different crystallographic orientation than the surrounding rims. In one representative 
grain the composition of the core is approximately An-50 while the rim varies between $A n-37$ near the inside and $A n-28$ at the edge.

TABLE 1: Mineralogical Composition of Igneous Rocks from the Dry Pass Batholith.

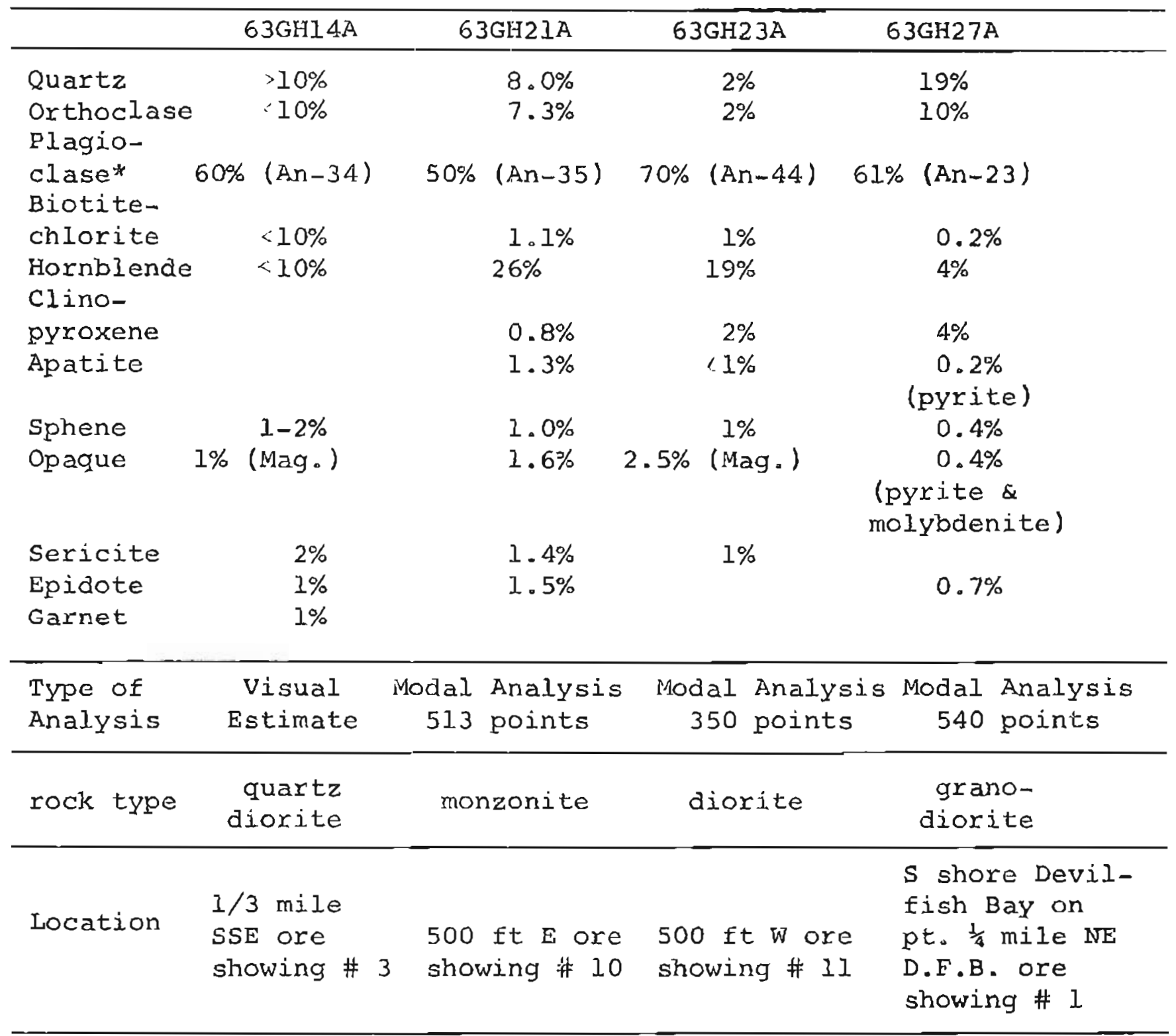

* Plagioclase composition given is the average of several unzoned grains. 
Pyroxene grains are commonly partly altered to hormblende, but most of the large hornblende phenocrysts contain no relict pyroxene and probably are the result of direct crystalization from the melt rather than alteration of pyroxene. Plagioclase grains, which are relatively small compared to those in the matrix, are present as inclusions in the hornblende and pyroxene phenocrysts. Apparently the mafic grains xeached their large size while the plagioclase grains were still small, and plagioclase continued to crystallize after crystallization of: the mafics ceased. Magnetite and sphene began crystallization with the mafics, but continued to form probably until after the end of plagioclase crystallization. Quartz and orthoclase are later than the plagioclase. Pyrite, epidote, and at least part of the quartz axe late and may be hydrothermal. Molybdenite is associated wi th the pyrite and is probably the same age.

The contact metamosphic effects around the batholith and its texture indicate clearly that it is of magmatic origin.

Dikes - Dikes were only recognized along the western side of the batholith where exposures are good. These are shown on the geologic map. For the most part they are of dioritic composition and appear to be off shoots Erom the batholith. Several aphanitic to medium grained dioritic dikes with hornblende phenocrysts occur west and north of sutter Lake. These are up to $20 \mathrm{ft}$ wide, strike at large angles to the batholi.th and appear to be nearly vertical. A magnetite showing $2 \frac{1}{2}$ ft wide, length unknown due to cover, occurs along the contact of one of these dikes with the marble country rock at ore showing \# 9 .

One-third mile northwest of ore showing \# 1 a hornblende lamprophyre dike about 40 ft wide occurs as rubble at the head of a small bight. The hornblende is euhedral in a chloritic groundmass. One-eighth mile further north a white felsite dike 20 ft wide occurs along the shore. It contains quartz and feldspar phenocrysts and an estimated one-half per cent disseminated pyrrhotite.

\section{Structure:}

A11 of the measured orientations of banding in the banded hornfels and marble have been plotted on an equal area stereographic net to illustrate the structural relationship of the two rock types with one another (Fig. I). The poles (perpendiculars) of the banding and foliation planes all fall roughly along a single great circle. This regular distribution of attitudes is the result of folding of rocks about an axis txending approximately $555 \mathrm{~W}$ with a $50^{\circ} \mathrm{SW}$ plunge. The structural homogeneity in the area indicates that the foliation 
Figure 1. Lower hemlophere, equal area projection

- - normal to follation or bedding (all attltudes taken in banded hornfela and marble are plotted)

O -. pole of great circle through dots

$x$ - axis of minor fold

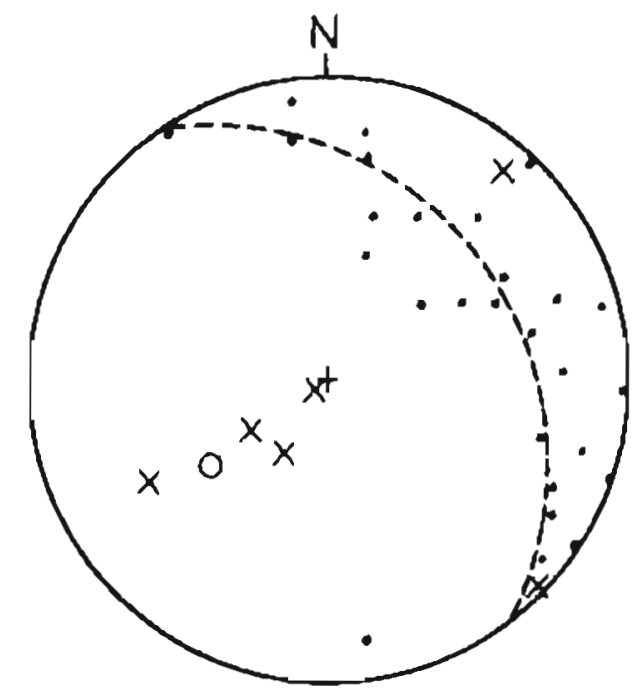

Flgure 2. The Angus Lillie molybdenum deposit

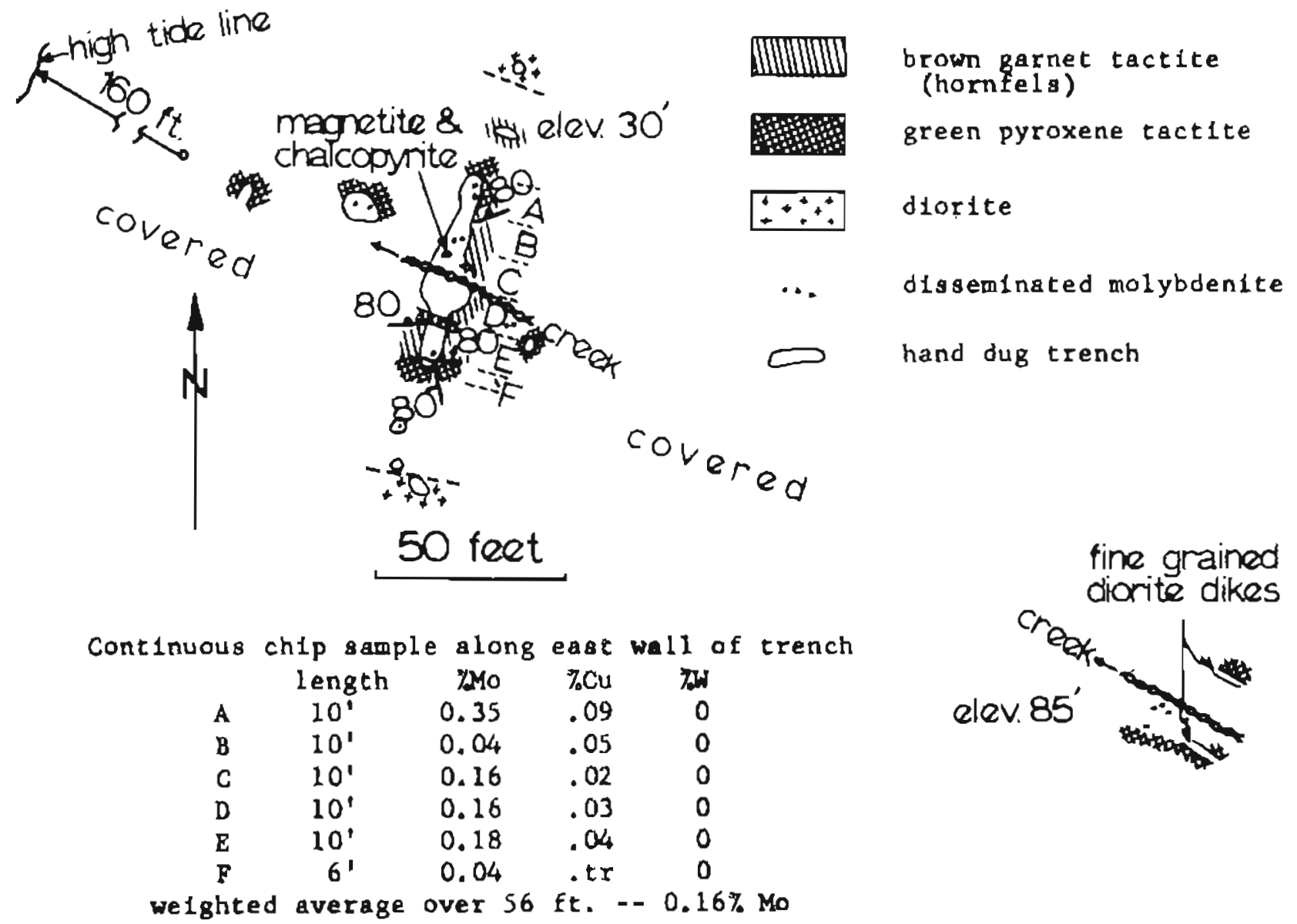


planes and gray bands in the marble were, before they were folded, paxallel to the sedimentary banding in the hornfels. Thus the planar structures in the marble represent original bedding planes. Due to the plastic behavior of the marble, these bedding planes have been folded on a scale of a few inches or less and sheared out so that only fold hinges and foliation surfaces parallel to the axial plase remain. The sinuous contact between the marble and banded siltstone is an indication that larger folds of this orientation are also present in the map area. A close approximation of the profile of these larger folds $c a n$ be seen by viewing the marble-hornfels contact with the eye at the northeast corner of the map looking southwest, down at an angle of 50\%, parallel to the plunge of the folds. Evidently these Folds are recumbent.

The fold axes in the map area trend at about right angles to the regional northwest trending folds described by Buddington and Chapin (1929). It is possible that the northwest folding is younger and, in the map area, has resulted in the refolding of beds previously folded on a smaller scale. This would account for the $50^{\circ}$ plunge of the fold axes in the map area. The homogeneity of the folding indicates passive introusion of the batholith in the map area.

\section{MINERAL, DEPOSITS}

Ore minerals occur in white marble, tan to green tactite, and diorite. Most of the showings occur in tactite, except for the largest, the shakan vein, which is in diorite. The principal known deposits in the map area are the shakan molybdenite-chalcopyritemagnetite vein and the Dry Pass molybdenite-chalcopyrite deposit. With the exception of the magnetite deposit at Devilfish Bay, the other showings in the map area are small exposures of molybdenum. chalcopyrite, and scheelite.

Shakan Molybdenum-Copper Deposit (ore showing \#2):

The following account is oased mainly on the report by Robinson (1946). The property was visited only briefly by the authors.

The Shakan molybdenum prospect occurs in a gently dipping $\left(10-20^{\circ} \mathrm{S}\right)$ shear zone of variable strike (N85W-N70E) cutting hornblende diorite. The zone is exposed sporadically for $800 \mathrm{ft}$ along its dip direction on a north-noxtheasterly trending west facing riage. In most of the pits along this length the shear zone appears 
to have a width varying between 4-6 feet. Mineralization consists of molybdenite, chalcopyrite, sphalerite, pyrite, and magnetite* associated with coarse grained orthoclase and with quartz, biotite, muscovite, and sphene along with veins of quartz, aduleria, and epidote. The ore and gangue are mainly restricted to the shear zone, with only minor amounts of disseminated sulfides in the intrusive immediately adjacent to it. Anomalous amounts of pyrite occur in the diorite in the area.

During World war $I$, an adit 570 feet long was driven and numerous surrace pits were dug. Since that time, no further development has been undertaken. Robinson's tonnage estimate was 15,000. 20,000 tons of 1.5 per cent MoS$_{2}$.

This property has been patented (Mineral survey 1450 A \& B; 218.08 acres) and is held by $A$. $J$. Industries, formerly the Alaska Juneau Gold Mining Company.

Angus Lillie Molybdenum Deposit (ore showing 拉 and Fig. 2):

This deposit consists of molybdenite and chalcopyrite disseminated in a band of cactite about 100 feet wide, which is bordered on either side by diorite. The tactite is composed of brown tactito (hornfels) and green tactite with gradational contacts between the two. At one place these rocks are interlayered, a structure that may represent bedding. No unreplaced blocks of marble or banded argillite were seen, however. The molybdenite is disseminated, occuring as joint coatings and scattered irregular masses, usually less than one-half inch in diameter. High grade ore occurs mainly in green tactite, rather than brown. Many angular blocks of high grade molybdenum-bearing green tactite ore a foot or more across (one example: $5.7 \% \operatorname{Mos}_{2}$ ) have been taken from the main trench. Ore of this type is irregularly distributed in the bedrock. Locally the green tactite carries an estimated one per cent or less disseminated powellite $\left(\mathrm{CaMOO}_{4}\right)$ which fluoresces golden yellow in ultra violet light. An area in the main trench $1-2$ feet across contained massive magnetitechalcopyrite-pyrite in green tactite. The magnetite is cut by chalcopyrite and pyrite veinlets. No molybdenite was seen with the magnetite and none of these minerals were seen with the molybdenite, although assays indicate the presence of some coppex. Bedrock cover at the main trench consists of one foot of black soil and humus. For the most part, it is thin over the surrounding area also. It is

* Not mentioned by Robinson but found in ore samples collected from the vein in the adit by the authors. 
possible that magnetite will be found to be associated with molybdenite elsewhere in the area, thereby allowing effective use of magnetometer in prospecting.

Microscopic examination shows the green tactite to contain carbonate and clinopyroxene with lesser amounts of garnet, epidote, and sphene. The brown tactite contains grossularite garnet and small grains of clinopyroxene and calcite. The rocks are evidently the result of replacement of marble by material derived from a magmatic source, probably the diorite.

\section{Minor Ore Showings:}

Due to heavy vegetal cover, the geology around these showings is in all cases poorly exposed.

$$
\text { Dry Pass map area - (3) At this locality at } 550 \text { feet in }
$$
elevation an old adit, now caved, was driven $580 \mathrm{E}$ for a reported distance of 100 feet in tan hornfels. Quartz on the dump contains disseminated pyrite and galena which assayed 0.6 per cent $\mathrm{Pb}, 0.05$ per cent $\mathrm{Cu}$, and 0.1 per cent Mo. About 100 feet northwest of the portal, a showing of scheelite occurs in quartz veins $\left(\mathrm{N} 80^{\circ} \mathrm{E}, 70^{\circ} \mathrm{N}\right.$ dip) which are associated with irregular white marble lenses in a shear zone. The country rock is tan hornfels. A chip sample across 5 Eeet assayed 1.4 per cent $\mathrm{WO}_{3}$.

(4) Down the hill from the old adit (作3) at an elevation of 470 feet another showing of disseminated molybdenite (with pyrite) occurs in quartz veinlets in a 4 foot shear zone (N75E, $80^{\circ} \mathrm{N}$ dip). The bedrock is tan hornfels composed entirely of garnet and quariz.

(5) Disseminated molybdenite in small quartz pods in white marble. A granitic dike intrusive into fine-grained amphibolite is exposed nearby.

(6) Disseminated molybdenite and crystalline garnet in quaxtz veins in white marble. Brown hornfels is exposed nearby.

(7) Pyrrhotite-chalcopyrite pods associated with green siliceous layers in marble. Similar origin to ore occurrence $n_{3}$ on Devilfish Bay.

(8) Small solid pyrrhotite-chalcopyrite pods associated with marble and garnet tactite near the diorite contact. pods are up to several inches thick and several feet long with an assay of 2.48 per cent $\mathrm{Cu}$ reported by Mr. Lillie. 
(9) Magnetite showings at contact between diorite dike and marble. They are $2^{\frac{1}{2}}$ feet wide, length unknown due to cover.

(10) Disseminated pyrite and chalcopyrite in gneiss which is banded roughly parallel to the sedimentary contact to the west. Mr. Lillie reports a 0.1 per cent $C u$ assay. A little molybdenite is visible in the rock. This is an anhedral-granular rock with hornblende-pyrrohotite-pyrite bands in a sugary matrix of quartz, plagioclase (An-30), orthoclase and biotite. Sphene, apatite, and epidote are also present. The rock has the same constituents as the granodiorite, but a typically gneissoid texture and a much higher percentage of quartz. This rock is probably a metamorphosed sedimentary rock, either along the contact or an inclusion in the diorite.

(11) Vuggy white quartz veins up to 1 foot wide containing scattered plates of molybdenite. Well terminated quartz arystals occur around vugs. The veins cut glomeroporphyritic hornblende diorite.

(12) Siliceous diorite with small amount of pyrchotite, pyrite, molybdenite, chalcopyrite float.

(13) Quartzose light green rock with disseminated scheelite near marble-diorite contact. One hundred feet south at same elevation a disseminated molybdenite show is present in tactite associated with medium grained diorite and green aphanitic dikes.

Devilfish Bay area - Devilfish Bay lies along the east side of the Dry Pass batholith. Brief examination of Angus Lillie's prospects on the south shore of the Bay indicates that the ore shows occur in tactite inclusions in the intrusive with marbie and banded graywacke-siltstone. Modal analysis of a specimen of the intrusive taken from the south shore of Devilfish Bay shows it to be granodiorite (see Table 1). The tactite is mainly fine grainel bxown garnet tactite or coarser grained light greenish tactite, both the result of additions of material to the sediments, probably from the batholith during the period of intrusion. In restricted areas, metalic ore minerals have also been added. The individual ore showings are located on the Devilfish Bay Index Map and shown in greater detail on the accompanying larger scale maps.

\section{WORLD AERONAUTICAL CHART MAGNETIC ANOMALY}

The World Aeronautical Charts published by the U.S. Coast and Geodetic Survey show many points of compass deviation caused by local magnetic anomalies. These are noted on the maps with an arrow 


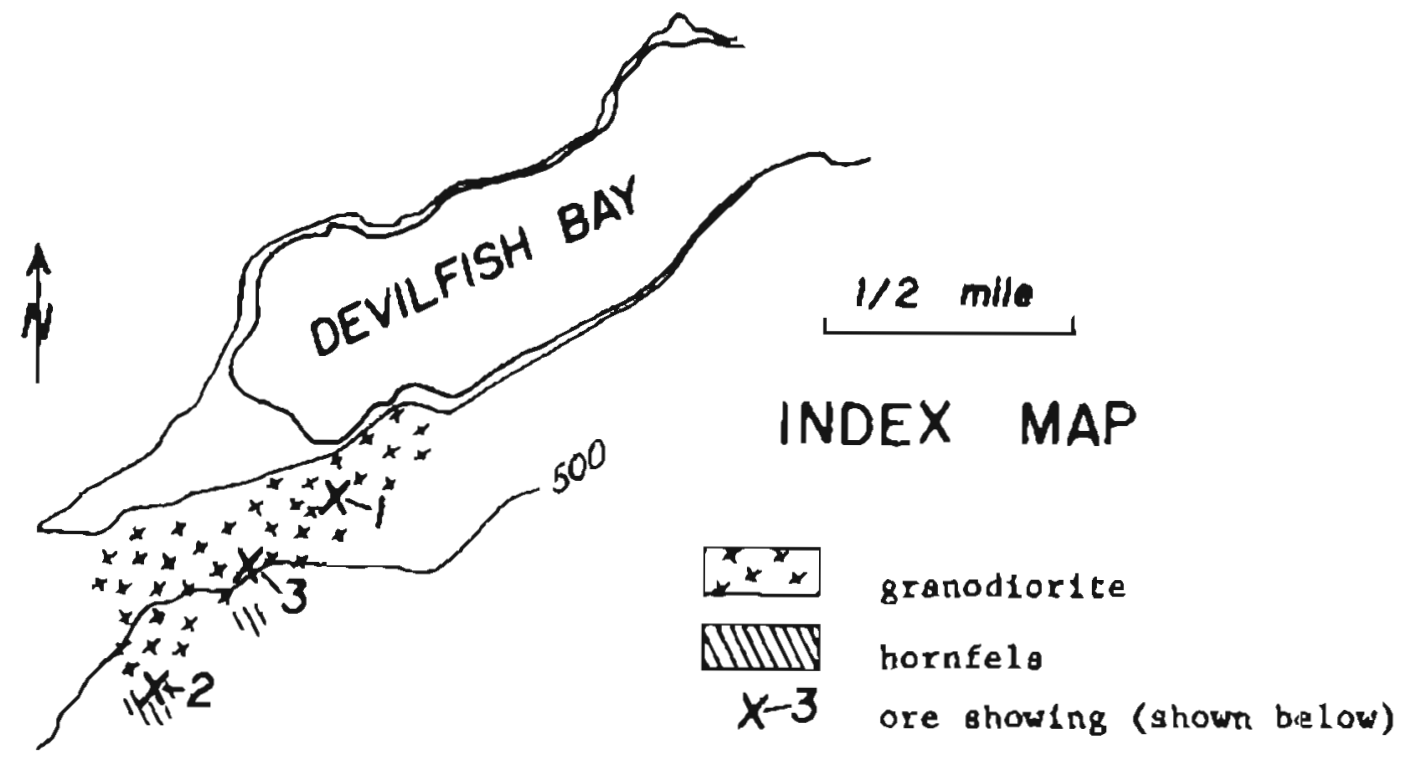

Devilfish Bay ore ghowling \#1
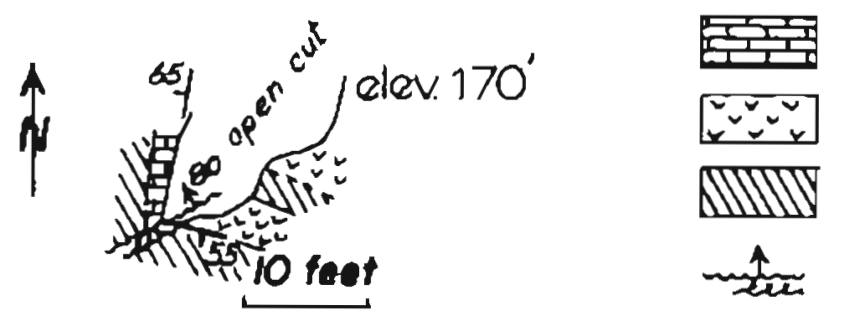

white marble

alaskite

tan hornfels (garnet, scapolite)

fault zone with dia-

seminated chalcopyrite

Chalcopyrite occurs along a fault in hornfels, asaoclated with Alaskite (quartz-feldspar rock). Molybdenum was found in dump. Pyrlte and trace of chalcopyrite within $50 \mathrm{ft}$. Of plt, whlle beyond rock is unfineralized hornblende granodlorite (?).

Devilfigh Bay ore showing \#2

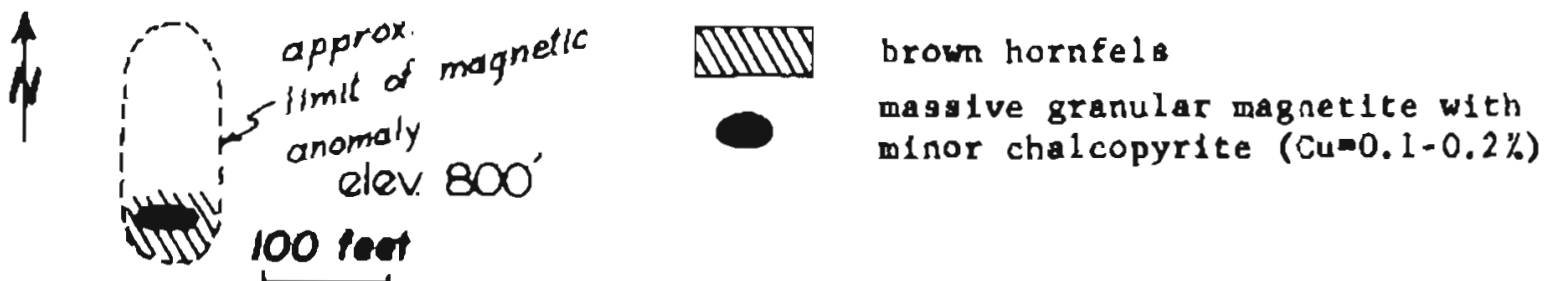


Devilfish Bay ore showing 3

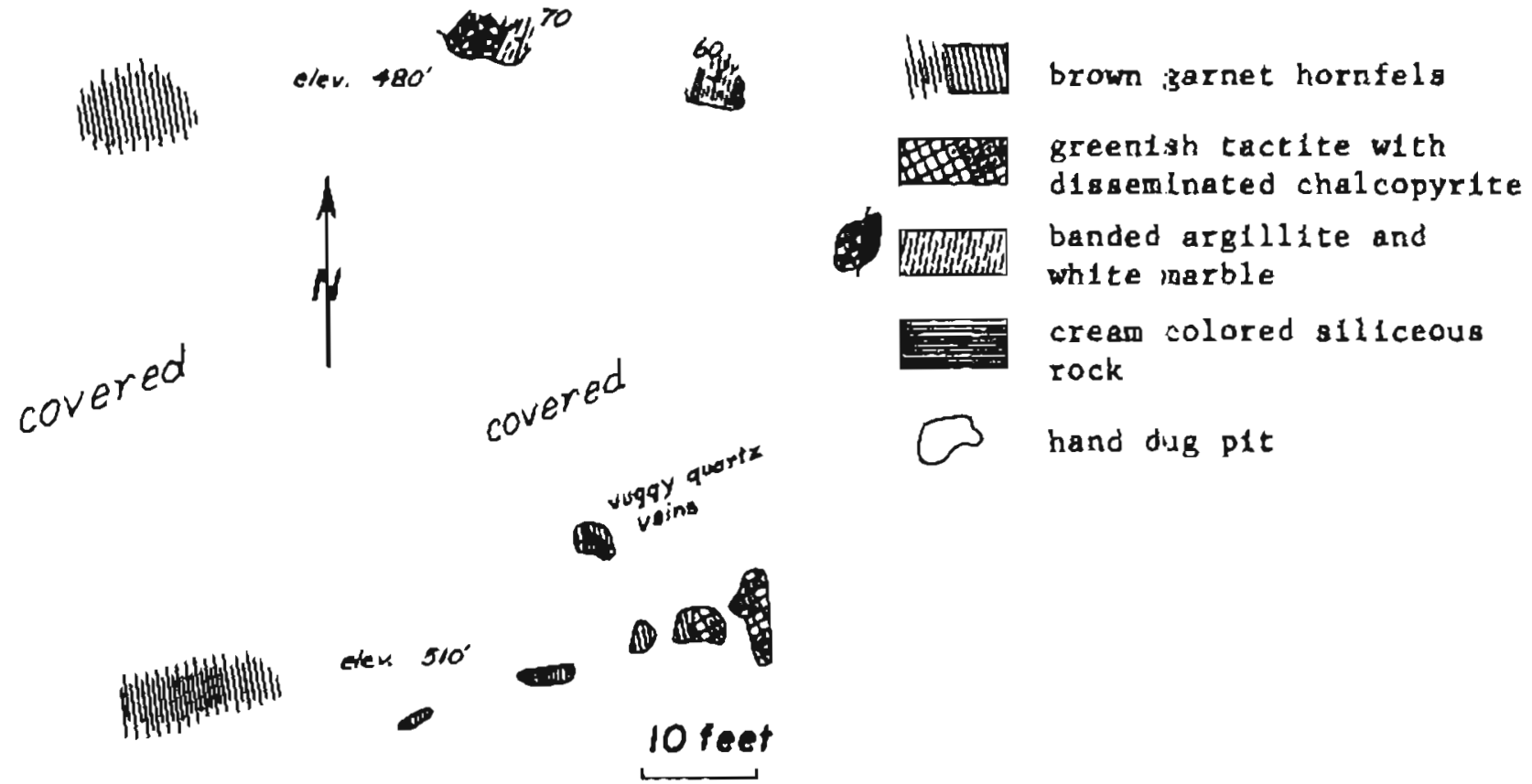

Area of scattered chalcopyrite showings asociated with sedimentary beds, brown garnet hornfels, and fiberous greenlah tactite. The greenish tactite is composed malnly of wollastonite, plus sume garnet and contains up to several per cent chalcopyrite in the areas exposed. 
pointing to the location and the degrees deviation given. While the significance of such anomalies is even more enigratic than the data on regular aeromagnetic maps, their possible geological significance is shown by the presence of similar notations at Klukwan, Snettisham, and Union Bay - all areas with known large magnetite deposits. Location of a $5^{\circ}$ compass deviation is show on the geologic map following page 1. This was taken from world Aeronautical Chart 138 (Mt. Fairweather). The ssociation of magnetite with chalcopyrite and molybdenite in the area makes this anomaly interesting as a possible guide to ore.

\section{SUMMARY AND CONCLUSIONS}

Three types of ore mineral occurrences have been found in the areas mapped. These are vein deposits in the diorite, contact metamorphic deposits in tactite close to diorite contacts, and disseminations in che diorite. The shakan vein is the only significant vein deposit known. The vein is composed of molybdenite, chalcopyrite, and magnetite closely associated with dikes and veins containing orthoclase, quartz, biotite, muscovite, spliene, and epidote. The deposit has been explored by open cuts and a 570 foot adit. Ten to twenty thousand tons of 1.5 per cent Mos2 ore have been outlined. Considerable massive chalcopyrite is exposed at the face in the adit and further work should extend the preserity-known limits of the ore. The best showing of contact netamorphic oxe is at the Angus lillie prospect. The oxe here is molybdenite with some chalcopyrite and powellite and with nearby pods of magnetite-chalcopyrite. The molybdenite ore is disseminated in a tactite re-entrant into the diorite and grades run up to more than 5 per cent: Mos 2 . At the main trench (shown on Fig. 2) the ore averages 0.16 per cent Mos 2 across a distance of 56 feet. Further work will be nocessary to evaluate the significance of this deposit.

Low grade disseminations of molybdenite accompanied in places by pyrite and chalcopyrite were seen east of sutter Lake near oxe showing \#II and on the south shore of Devilfish Bay (63GH27A. described on Table I). Such disseminaied occurrences suggest the possibility that porphyry type deposits may be present in the intrusive where gtructural condiciors have been propitious.

The presence of these various types of ore in or closely associated with the intrusive suggests that the intrusive itself was the source of these elements. In accord with this is the evidence in thin section of late magmaicic or early hydrothermal crystallizaiion of quartz, pyrite, epidote, and molybdenite. These minerals followed the late magmatic crystallization of orthoclase, quartz, magnetite, and sphene. At the shakan deposit the veins and dikes 
contain the same ore and rock-forming minerals in close association, giving a further indication of the close association of the ore minerals with the late magmatic rock-forming minerals of the intrusive and thereby strengthening the conclusion that the ore was derived from the intrusive itself during cooling.

The known deposits are indications of the ore potential of the Dry Pass diorite. The cooling intrusive evidently carried anomalous quantities of molybdenum and where open spaces and/or limy rocks along igneous contacts were present, ore bodies rere formed. There is no reason to believe that all such deposits have been found. The discovery of the promising Lillie molybdenum prospect by Mr. Iillie along a creek 250 feet from tide water at a good harbor not far from the long known shakan deposit indicates that the prospecting has by no means been exhaustive.

\section{SUGGESTIONS FOR PROSPECTING}

1. Shakan vein: Could possibly be traced by a soil geochemical survey and diamond drilling to shallow depths. If the magnetite content is sufficiently widespread, the vein could be traced by a detailed ground magnetometer survey.

2. Angus Lillie molybdenite-chalcopyrite prospect: Should be opened up by further blasting and bulldozer trenching followed by drilling if results are encouraging. Here also a ground magnetometer survey might be of value.

3. Devilfish Bay copper showing (\#l): Could probably be traced by a soil geochemical survey.

4. The association of magnetite with molybdenite and chalcopyrite in many of the deposits suggests that stream sediment and soil geochemical sampling for copper or heavy metals plus ground magnetometer surveying in areas of geochemical anomalies may be effective. The area along the margins of the batholith is favorable for ore deposits and should be surveyed in this manner. In particular, the area in the vicinity of the World Aeronatical Chart magnetic anomaly should be prospected.

5. Air photo interpretation: Particular attention should be given topographic linears which could represent faults cutting the intrusive. Deposits similax in origin to the shakan vein could be located along such faults. 


\section{REFERENCES CITED}

Buddington, A.F. and T. Chapin

1950. Geology and Mineral Deposits of Southeast Alaska. U.5. Geological Survey Bulletin 800, Plate 1.

Robinson, G.D.

1946. Molybdenite Deposit at Shakan, Kosciusko Island, U.S. Geological Survey Bulletin 947-B, p. 19-30. 